\title{
Glycemic Control and the Heart: The Tale of Diabetic Cardiomyopathy Continues
}

\author{
Miriam Longo ${ }^{1,2,+}$, Lorenzo Scappaticcio ${ }^{1,+}{ }^{+}$, Paolo Cirillo ${ }^{1}$, Antonietta Maio ${ }^{1}$, Raffaela Carotenuto ${ }^{1,2}$, \\ Maria Ida Maiorino ${ }^{1,2} \mathbb{D}$, Giuseppe Bellastella ${ }^{1,2} \mathbb{D}$ and Katherine Esposito ${ }^{1,2, *, \ddagger}$
}

1 Department of Advanced Medical and Surgical Sciences, University of Campania "Luigi Vanvitelli", 80138 Naples, Italy; miriam.longo@unicampania.it (M.L.); lorenzo828@virgilio.it (L.S.); paolo.cirillo10@hotmail.com (P.C.); antonietta.maio@unicampania.it (A.M.); raffacarotenuto@gmail.com (R.C.); mariaida.maiorino@unicampania.it (M.I.M.); giuseppe.bellastella@unicampania.it (G.B.)

2 Division of Endocrinology and Metabolic Diseases, University of Campania "Luigi Vanvitelli", 80138 Naples, Italy

* Correspondence: katherine.esposito@unicampania.it; Tel.: +39-08-156-65031

$\dagger$ These authors contributed equally to this work.

$\ddagger$ Current address: Dipartimento di Scienze Mediche e Chirurgiche Avanzate (DAMSS), University of Campania “Luigi Vanvitelli", Piazza Luigi Miraglia 2, 80138 Naples, Italy.

check for updates

Citation: Longo, M.; Scappaticcio, L.; Cirillo, P.; Maio, A.; Carotenuto, R.; Maiorino, M.I.; Bellastella, G.; Esposito, K. Glycemic Control and the Heart: The Tale of Diabetic Cardiomyopathy Continues. Biomolecules 2022, 12, 272. https:// doi.org/10.3390/biom12020272

Academic Editors: Giuseppe

Limongelli and Martina Caiazza

Received: 3 September 2021

Accepted: 1 February 2022

Published: 8 February 2022

Publisher's Note: MDPI stays neutral with regard to jurisdictional claims in published maps and institutional affiliations.

Copyright: (C) 2022 by the authors. Licensee MDPI, Basel, Switzerland. This article is an open access article distributed under the terms and conditions of the Creative Commons Attribution (CC BY) license (https:// creativecommons.org/licenses/by/ $4.0 /)$.

\begin{abstract}
Cardiovascular diseases are the leading cause of death in people with diabetes. Diabetic cardiomyopathy (DC) is an important complication of diabetes and represents a distinct subtype of heart failure that occurs in absence of cardiovascular diseases. Chronic hyperglycemia and hyperinsulinemia along with insulin resistance and inflammatory milieu are the main mechanisms involved in the pathophysiology of DC. Changes in lifestyle favoring healthy dietary patterns and physical activity, combined with more innovative anti-diabetes therapies, are the current treatment strategies to safeguard the cardiovascular system. This review aims at providing an updated comprehensive overview of clinical, pathogenetic, and molecular aspects of DC, with a focus on the effects of antihyperglycemic drugs on the prevention of pump dysfunction and consequently on cardiovascular health in type 2 diabetes.
\end{abstract}

Keywords: type 2 diabetes; diabetic cardiomyopathy; cardiovascular disease; heart failure; glucose control; glucose-lowering agents

\section{Introduction}

Cardiovascular disease (CVD) represents a challenging issue in the management of diabetes mellitus (DM) and the main cause of death in diabetic patients. Heart failure (HF) is one of the major causes of morbidity and mortality from cardiovascular disease [1]. Recent studies have found that rates of incident HF hospitalization were twofold higher in patients with diabetes compared with those without [1,2]. Diabetic cardiomyopathy (DC) is a subtype of HF defined as the diabetes-associated structural and functional myocardial dysfunction that occurs in absence of conventional cardiovascular diseases (i.e., coronary artery disease, uncontrolled hypertension, valvular heart diseases or congenital heart diseases) [3,4]. DC often appears in the context of CVD; however, it may present as the unique manifestation of cardiac disease [4].

The three major risk factors for DC are high hemoglobin $\mathrm{A} 1 \mathrm{c}(\mathrm{HbA} 1 \mathrm{c})$, long disease duration, and older age [4,5]. It has been estimated that $22 \%$ of patients diagnosed with idiopathic cardiomyopathy have underlying DM [6]. Moreover, in studies published after 2000, in which more advanced echocardiographic imaging techniques were used, the prevalence of diastolic dysfunction in the population affected by type 2 DM (DMT2) without 
the conventional CVD varied between $28 \%$ and $75 \%$. Data reporting the prevalence rate of DC in type 1 diabetes are limited; however, there is evidence from a few observational studies that type 1 diabetes even affects heart function with different mechanisms as compared with those described in DMT2 [6,7].

This review aims at providing an updated comprehensive overview of clinical, pathogenetic, and molecular aspects of DC, with a focus on the effects of anti-hyperglycemic drugs on the prevention of pump dysfunction and consequently on cardiovascular health in DMT2.

\section{Clinical Aspects of Diabetic Cardiomyopathy}

Independently of traditional risk factors, diabetes-related heart anatomical and functional alterations, including fibrosis, left ventricle (LV) remodeling, and impaired contractility, led to the four stages or subgroups of DC (Table 1) [8-10]. DC is regarded as a restrictive phenotype with LV hypertrophy and diastolic dysfunction during the first stages, and a dilatative phenotype with reduced ejection fraction at late stages [10]. Specifically, patients with stage 1 are usually asymptomatic and have only diastolic dysfunction. On the other hand, in stages 2 and 3 there are both diastolic and systolic dysfunctions. In patients at early stage, although myocardial dysfunction is subclinical, stress situations (i.e., exercise) can induce an impairment of systolic performance with altered contractile reserve [8,9]. This subclinical systolic dysfunction could be associated with diastolic dysfunction, which precedes the development of both systolic dysfunction with reduced LV ejection fraction (LVEF). Otherwise, patients in stage 4 have symptomatic HF and coronary heart disease [8,9]. Although the distinction of these four forms has important therapeutic and prognostic consequences, its translation in clinical practice is difficult since it is challenging to distinguish when heart abnormalities are due to DC or to coronary artery disease or other diseases unrelated to diabetes [4].

Table 1. Stages or subgroups of diabetic cardiomyopathy.

\begin{tabular}{lcccc}
\hline Characteristics & Stage 1 & Stage 2 & Stage 3 & Stage 4 \\
\hline Progression & Early phase & Middle phase & $\begin{array}{c}\text { Middle/late } \\
\text { phase }\end{array}$ & Late phase \\
\hline Function & $\begin{array}{c}\text { Diastolic } \\
\text { dysfunction }\end{array}$ & $\begin{array}{c}\text { Diastolic and } \\
\text { systolic } \\
\text { dysfunction }\end{array}$ & $\begin{array}{c}\text { Diastolic and } \\
\text { systolic } \\
\text { dysfunction }\end{array}$ & $\begin{array}{c}\text { Diastolic and } \\
\text { systolic } \\
\text { dysfunction }\end{array}$ \\
\hline Anatomy & $\begin{array}{c}\text { Hypertrophy; } \\
\uparrow \text { LV mass and } \\
\text { wall thickness; } \\
\text { dilatation; } \\
\text { fibrosis }\end{array}$ & $\begin{array}{c}\text { Dilatation; } \\
\text { fibrosis; } \\
\text { microangiopathy }\end{array}$ & $\begin{array}{c}\text { Dilatation; } \\
\text { fibrosis; } \\
\text { micro- and } \\
\text { macroangiopathy }\end{array}$ \\
\hline Troponins & NYHA I & NYHA II & NYHA II-III & NYHA II-IV \\
\hline
\end{tabular}

$\uparrow$ stands for increase; + stands for increased levels; HF, hearth failure; LV, left ventricle; NYHA, New York Heart Association.

\section{Imaging and Laboratory}

Echocardiography, also known as cardiac ultrasound (cUS), is the most sensitive test to diagnose DC [7]. It allows the evaluation of anatomical and functional alterations in the LV, including the diastolic dysfunction, LV filling pressure, and myocardial perfusion reserve [4,7]. Moreover, cUS can also exclude other causes of cardiac damage. The addition of tissue doppler imaging (TDI) currently improves its diagnostic accuracy in measuring myocardial velocities, leading to higher performance in detecting diastolic 
dysfunction in patients with normal systolic function [7,11]. Cardiac magnetic resonance imaging (cMRI) is the gold standard for the identification of interstitial fibrosis and extracellular matrix expansion, which are important pathological features of patients with DC [7]. The assessment of myocardial fibrosis by cMRI could have a prognostic value in patients with DC without any evidence of underlying CVD, identifying patients at high risk of future cardiovascular events [12]. Interestingly, cardiac abnormalities assessed by cMRI have been associated with the up-regulation of specific microRNAs targeting the extracellular matrix [13].

Among the cardiovascular biomarkers, brain natriuretic peptide (BNP) could be the most useful one to evaluate LV dysfunction, as well as in asymptomatic patients in the subclinical phase [14].

Interestingly, persistent microalbuminuria can be used as a marker of diffuse fibrosis and diastolic dysfunction, based on its association with cardiac extracellular volume [15].

\section{Pathophysiology of Diabetic Cardiomyopathy}

A wide variety of molecular mechanisms underlie the development and progression of DC, which are partially different from those promoted by hypertension or ischemia (Figure 1). Hyperglycemia and hyperinsulinemia along with insulin resistance are the main pathogenetic drivers of the metabolic alterations that lead to the DC [4,7]. In the setting of hyperglycemia, insulin resistance, and hypertriglyceridemia, there is a reduction in the myocardium's ability to use glucose as an energy source, and it subsequently switches to free fatty acids (FFAs). Specifically, the key mechanisms involved in the pathophysiology of DC are oxidative stress, hyperglycemia and glucotoxicity, lipotoxicity, advanced glycated end-products (AGEs) deposition, inflammation, cardiac autonomic neuropathy (CAN), and microvascular dysfunction [16].

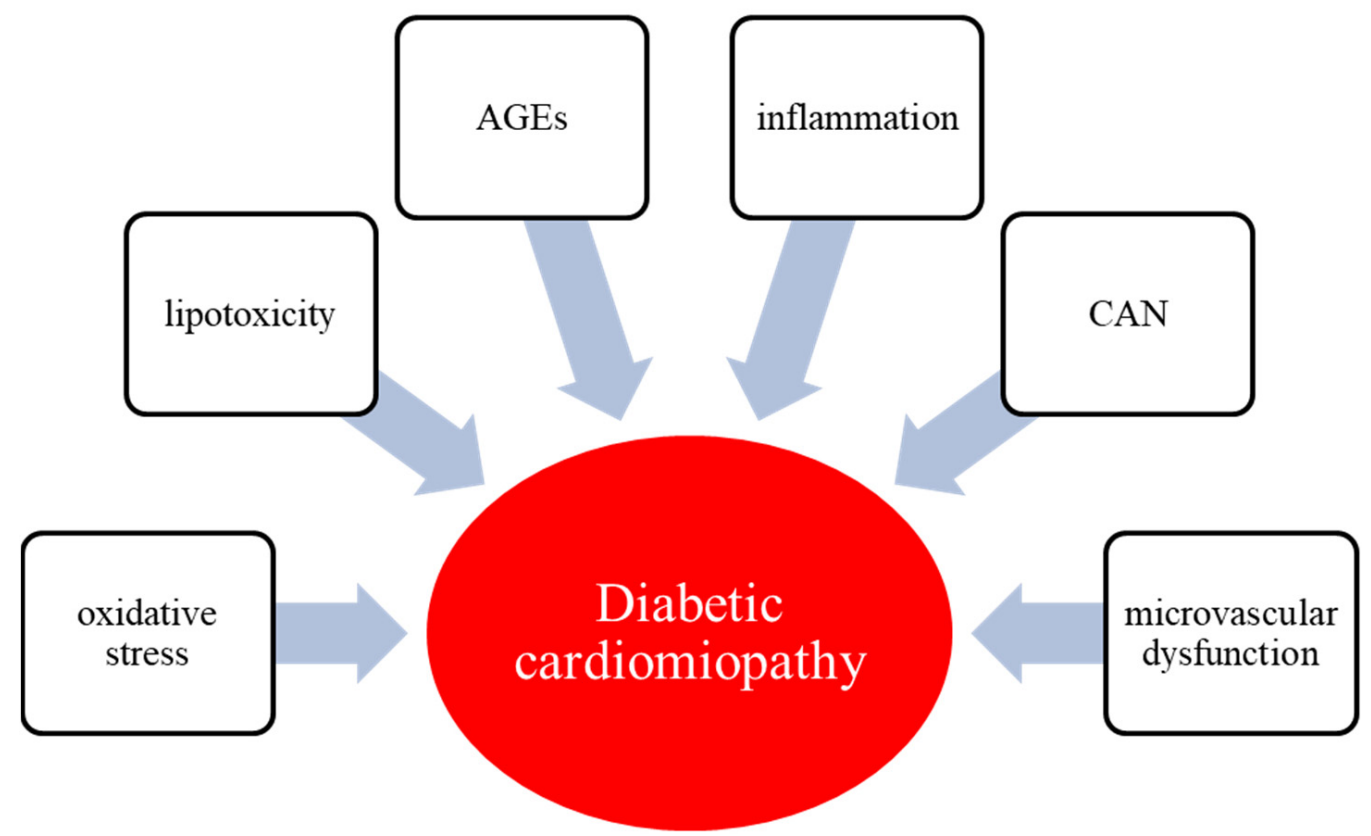

Figure 1. Molecular mechanisms underlying the development and progression of DC. AGEs, advanced glycated end-products; CAN, cardiac autonomic neuropathy.

\subsection{Hyperglycemia and Glucotoxicity}

Hyperglycemia is a major etiological factor in the development of DC. It enhances the production of FFA and different growth factors, causing abnormalities in substrate supply and utilization, calcium homeostasis, and lipid metabolism [17]. Furthermore, it contributes to the excessive release of reactive oxygen species (ROS), which are responsible for oxidative stress, impairment of gene expression, abnormal signal trans- 
duction, and cardiomyocytes apoptosis. The effects of growth factors on connective tissue, together with fibrosis and the formation of AGEs, increase the stiffness of diabetic hearts [18]. A healthy heart can metabolize a range of substrates, including FFA, glucose, amino acids, ketones, and lactate, in order to produce ATP $[19,20]$. Particularly, the oxidation of FFA, glucose, and pyruvate represent the main contributors for ATP formation and energy storage. The activity of pyruvate dehydrogenase (PDH), which is a key enzyme regulating the balance between carbohydrate and fat metabolism in the heart, appears to be decreased in diabetes and associated with the impairment of the pyruvate oxidation [21,22]. The dissociation of glycolysis and pyruvate oxidation in the diabetic heart results in the accumulation of glycolytic intermediates, which are responsible for the activation of specific glucose-sensing transcription factors $[23,24]$. Glycolytic intermediates decrease the sarcoplasmic reticulum calcium ATPase 2a (SERCA2a) expression [25], which is essential in calcium homeostasis, resulting in diastolic dysfunction [26]. Indeed, SERCA2a expression in the heart appeared to be decreased in diabetes [26,27]. Finally, hyperglycemia induces the production of AGEs and decreases the production of nitric oxide (NO) in coronary endothelial cells, leading to upregulation of endothelial vascular growth factor (VEGF) pathway. This metabolic abnormality causes fibrosis of capillaries with consequent impairment of myocardial functional reserve [7]. Therefore, uncontrolled hyperglycemia and subsequent metabolic changes triggered by these factors are responsible for a status of cardiac glucotoxicity and myocardial dysfunction [28].

\subsection{Lipid in Diabetic Cardiomyopathy}

The relationship between dyslipidemia, inflammation, and cardiovascular (CV) health in type 2 diabetes mellitus is complex. The status of insulin resistance and chronic low-grade inflammation increases plasma triglycerides (TG) levels [29]. Inflammatory mediators also enhance the production of matrix-metalloproteinases (MMPs) that, together with TG, reduce high-density lipoprotein cholesterol (HDL) levels. All these factors promote structural and functional impairment of the CV system [30]. Increased circulating TG levels are associated with intracardiac accumulation of fatty acids and, thus, enhanced fatty acid $\beta$-oxidation and impaired insulin metabolic signaling in diabetic hearts [31]. Additionally, in diabetes, cardiomyocytes often display increased expression of peroxisome proliferator-activated receptor- $\alpha$ (PPAR- $\alpha$ ), associated with increased FFA uptake, triacylglycerol accumulation, and reduced glucose utilization [32]. Abnormal lipid metabolism often accelerates the development of DC. Indeed, there is an increased release of FFA from adipose tissue, which in turn leads to the FFA transport in myocyte sarcolemma [33]. The cluster of differentiation 36 (CD36), which is located predominantly on the cell surface, promoting the FFA uptake in both sarcolemma and endosomal membranes, is overexpressed in diabetic hearts [34]. Conversely, GLUT4, which is an important glucose membrane transporter, is internalized in the cardiomyocytes, assuming an intracellular location [34]. The reduced glucose uptake promotes a metabolic shift toward FFA oxidation, resulting in decreased cardiac performances [35,36]. Indeed, CD36 knockout mice showed a 70\% reduction in FFA uptake in cardiomyocytes [37], and CD36 deficiency prevents lipotoxic cardiomyopathy [38,39]. Some lipid metabolites, including diacylglycerols and ceramides, impair insulin metabolic signaling, further promoting cardiac damage. Increased levels of diacylglycerols in cardiomyocytes compromise glucose metabolism through activation of protein kinase $C$ (PKC) isoforms, thereby reducing insulin metabolic signaling and NO production [31]. Therefore, excessive accumulation of lipids and toxic intermediates contributes to cardiac insulin resistance, reduced NO bioavailability, inflammation, fibrosis, and diastolic dysfunction in DC [32]. 


\subsection{Oxidative Stress}

In the setting of diabetes, both increased production of ROS and impairment of endogenous antioxidant mechanisms play an essential role in both mitochondrial damage and cardiac fibrosis [40]. In DC, the antioxidant factors, like superoxide dismutase (SOD) and glutathione peroxidase (GSH-Px), are reduced in cardiomyocytes, and ROS generation is dramatically increased, leading to high oxidative stress [41]. Moreover, the continuous production of ROS induces the activation of the TGF $\beta 1 /$ Smad3 signaling pathway, which promotes the expression of several fibrotic factors, as $\alpha$-SMA, collagen I, and collagen III in diabetic heart [42]. Therefore, therapeutic molecules and agents that counteract ROS generation and the related cardiac fibrosis may represent a potential therapeutic strategy for DC

\subsection{Endothelial Dysfunction}

The integrity of vascular endothelial cells constitutes the essential key basis of CV health. A healthy endothelium generates various vasodilating factors, such as NO, prostacyclin, bradykinin, and endothelium-derived hyperpolarizing factor; moreover, it also produces vasoconstrictor agents including endothelin and angiotensin II. Hyperglycemia can impair the physiological homeostasis of the endothelium. This may result in increased leukocyte adhesion and permeability, and reduced fibrinolysis, activating the diacylglycerol (DAG)-PKC signaling pathway $[43,44]$. PKC is a family of serine-threonine kinases that has been previously reported to be associated with vascular permeability in diabetes $[45,46]$. Activation of this pathway may contribute to diabetic endothelial dysfunction in several tissues, including the heart, retina, and kidney [47]. However, the precise pathway that leads to increased endothelial cell permeability and leukocyte adhesion by PKC activation remains still unclear.

\subsection{Inflammation}

Inflammation has been recognized as a key common pathogenic process of lipid and glucose excess. Since DM is recognized as an inflammatory disease, the induction of pro-inflammatory genes and proteins has been reported as one of the main risk factors for myocardial injury [16]. In addition, an inflammatory myocardial injury may be amplified by increased ROS levels. The nuclear factor-KB (NF-kB) is mainly implicated in inflammatory responses. NF-KB induces the expression of proinflammatory cytokines, such as TNF- $\alpha$, IL-6, pro IL1- $\beta$, and pro-IL-18 in the heart. NF-kB can also induce the expression of NLRP3 inflammasome [48]. The latter seems to be a novel molecular marker of DC. The activation of NLRP3 inflammasome leads to recruitment of procaspase- 1 . Activated caspase- 1 processes many inflammatory mediators, such as interleukin- $1 \beta$ and interleukin-18 precursors. An NF-kB-positive feedback further increases NLRP3 inflammasome assembly and procaspase- 1 activation and pro-interleukin- $1 \beta$ processing and maturation, generating an inflammatory vicious cycle [49]. Meanwhile, increased monocyte/macrophage migration through the coronary endothelium increases resident cardiac macrophages, which acquire a pro-inflammatory profile (M1) under conditions of enhanced oxidative stress induced by increased ROS and reduced NO bioavailability [50]. All these pathways contribute to cardiomyocytes dysfunction and the development of DC.

\subsection{AGES}

There is evidence that AGEs contribute to the development and progression of diabetic heart dysfunction. Chronic hyperglycemia results in intra- and extracellular AGEs production, by non-enzymatic reactions between reducing sugars with amino groups of nucleic acids, lipids, peptides, and proteins. Once formed, AGEs interact with receptors for advanced glycation end products (RAGEs), triggering a series of vascular and myocardial damage, resulting in diastolic and systolic dysfunction [51]. AGEs may bind RAGE, leading to maladaptive inflammatory gene expression, thus 
activating mitogen-activated protein kinase (MAPK) and Janus kinase (JAK) pathways in vascular and cardiac tissues. Meanwhile, AGEs are involved in increasing the production of ROS, which further promotes inflammation and fibrosis [33]. AGEs-induced modification of extracellular matrix and other structural proteins may provide a reduction of myocardial compliance and myocardial fibrosis [16]. Interestingly, in a mouse model of type 1 diabetes, administration of a RAGE antagonist prevented AGEs/RAGE signaling-mediated increase in myocardial collagen, fibrosis, stiffness, and diastolic dysfunction [52].

\section{7. $C A N$}

Hyperglycemia can activate multiple pathways involved in the pathogenesis of CAN. The majority of these pathways are related to the metabolic and/or oxidative state of neuronal cells. Oxidative stress can induce DNA damage, leading to activation of PARP and inhibition of GAPDH [53]. This in turn can activate multiple molecular mechanisms, including the polyol pathway, the hexosamine pathway, as well as activation of PKC and increased production of AGEs, which correlate with the severity of autonomic nerve abnormalities in patients with DM [53,54]. Particularly, the hyperadrenergic state characterizing the CAN promotes the development of interstitial fibrosis and diastolic dysfunction, also through the increased activation of the renin-angiotensin-aldosterone system (RAAS) [55].

\section{Role of Glucose Control in Diabetic Cardiomyopathy}

There is evidence that poor glycemic control correlates with an increased risk of heart failure among individuals with diabetes [56]. About a 1\% increase in HbA1c is associated with an $8 \%$ increased risk of heart failure [56,57]. In a recent Chinese study on 64 adult subjects with type DMT2 and 30 healthy controls, LV myocardial function, evaluated by cMRI, was impaired in patients with uncontrolled DMT2 (HbA1c $\geq 7 \%$ ) and diabetes duration < 10 years as compared with healthy control [58]. Moreover, poor glucose control was an independent predictor of LV myocardial dysfunction in this population. Furthermore, high $\mathrm{HbA1c}$ variability is associated with increased risk of all-cause and cardiovascular mortality, as well as diabetic complications [59]. These findings suggest that achieving adequate glycemic control may be useful to reduce the burden of diabetes-related CVD and thus preserve CV health in people with diabetes. In a recent meta-analysis with meta-regression of 15 cardiovascular outcome trials (CVOTs) including 138,250 patients with T2DM, there was a robust relationship between the reduction in achieved $\mathrm{HbA} 1 \mathrm{c}$ at the end of the trial and the $\mathrm{HR}$ reduction for major cardiovascular events, mainly driven by the reduction of non-fatal stroke, with no effect on HF [2].

A multifactorial approach that includes lifestyle modification and appropriate medical treatment of DMT2, hypertension, and dyslipidemia is essential to preserve pump function in people with diabetes. Several different new classes of glucose-lowering agents have been recently introduced in the market. Some of them have shown many cardioprotective effects beyond their ability to control hyperglycemia, with beneficial effects in preventing cardiovascular mortality and hospitalization due to HF (Table 2). However, with the exception of some experimental preclinical researches and very limited clinical studies, there is little evidence on the effects of glucose-lowering treatment in the specific setting of DC. 
Table 2. Summary of the main effects of different glucose-lowering agents on diabetic cardiomyopathy and heart failure.

\begin{tabular}{|c|c|c|}
\hline Glucose-Lowering Agent & Mechanisms of Action & Effects on Pump Function \\
\hline Metformin & $\begin{array}{l}\downarrow \text { insulin resistance and TNF- } \alpha \text { production } \\
\downarrow \text { cardiomyocytes and fibroblast LV remodeling } \\
\uparrow \text { production of NO } \\
\uparrow \text { systolic and diastolic function }\end{array}$ & $\begin{array}{l}\text { No significant effects on HF } \\
\text { hospitalization }\end{array}$ \\
\hline SGLT-2i & $\begin{array}{l}\downarrow \text { weight and blood pressure } \\
\uparrow \text { osmotic diuresis and natriuresis } \\
\downarrow \text { sodium-hydrogen exchanger (NHE) } \\
\downarrow \text { myocardial injury } \\
\uparrow \text { LV function }\end{array}$ & $33 \%$ reduced risk of HF hospitalization \\
\hline GLP-1RAs & $\begin{array}{l}\downarrow \text { inflammatory myocardial remodeling } \\
\downarrow \text { inflammatory pathways in cardiomyocytes } \\
\uparrow \text { glucose uptake and coronary blood flow }\end{array}$ & $10 \%$ reduced risk of HF hospitalization \\
\hline DPP-4i & $=/ \uparrow$ diastolic function & $\begin{array}{l}\text { No significant effect on HF } \\
\text { hospitalization ( } \uparrow \text { risk of HF } \\
\text { hospitalization only with saxagliptin) }\end{array}$ \\
\hline Sulfonylureas & $\begin{array}{l}\uparrow \text { hypoglycemia risk } \\
\uparrow \text { weight }\end{array}$ & $\begin{array}{l}\text { No significant effect on HF } \\
\text { hospitalization }\end{array}$ \\
\hline Thiazolidinediones & $\begin{array}{l}\uparrow \text { weight } \\
\uparrow \text { edema } \\
\downarrow \text { inflammation, lipid and protein metabolism } \\
\uparrow \text { vascular endothelial function }\end{array}$ & $\uparrow$ risk of HF hospitalization \\
\hline
\end{tabular}

\section{Lifestyle Changes}

A healthy dietary pattern together with regular physical activity, which represent the first line therapeutic strategies for T2DM, may be useful to prevent and treat DC in individuals with diabetes [33]. Aerobic exercise and caloric restriction of fat and refined carbohydrate intake seem to improve insulin resistance, reduce myocardial triglyceride content, and improve diastolic LV dysfunction [33]. Indeed, in a study of 11 overweightto-obese male patients with T2DM, 12-weeks of progressive endurance/strength training was effective in improving insulin sensitivity, LVEF, cardiac index, and cardiac output, with no variation in cardiac lipid content [60]. A Mediterranean dietary pattern characterized by a high proportion of mono and polyunsaturated fat, a small portion of red meat, and high quantities of olive oil has demonstrated many cardiovascular benefits, by decreasing inflammatory status, and improving lipid profile, endothelial dysfunction, and insulin sensitivity [61,62]. In particular, in a recent observational study on 9316 men and 27,645 women, including also people with diabetes, a higher adherence to a Mediterraneanstyle diet evaluated by modified Mediterranean Diet Scores (mMDS) was associated with a $12 \%$ reduced risk of HF in men but not in women [63]. Consequently, a healthy lifestyle, including the assumption of the Mediterranean diet, can be useful to preserve heart pump function in T2DM.

\section{Diabetes Therapy and DC}

Nowadays, there are several treatment options targeting differing mechanisms of actions for improving glycemia, in people with DM and CVD. In the following paragraph, we will discuss the effects of anti-hyperglycemic agents and lipid-lowering therapy on $\mathrm{CV}$ health in DM. 


\subsection{Metformin}

Metformin is the first-line oral anti-hyperglycemic treatment in the management of DMT2. It belongs to the class of biguanide drugs. Initially, its use was contraindicated in patients with diabetes and HF, due to the potential increased risk of lactic acidosis. In 2006, the FDA removed this contraindication from metformin's product label, and a further systematic review showed that metformin was associated with reduced all-cause mortality, without increased risk of hospital admission in patients with HF and diabetes [64].

However, metformin should be stopped in case of acutely decompensated HF, sepsis, or hypoperfusion conditions in order to prevent lactic acidosis. Metformin seems to exert several favorable effects on the pathophysiology of DC, by decreasing insulin resistance and TNF- $\alpha$ production, reducing cardiomyocytes and fibroblast LV remodeling, increasing the production of $\mathrm{NO}$, and improving systolic and diastolic function $[7,65]$.

Both in vivo and in vitro studies showed that metformin can improve cardiac function and alleviate apoptosis by activating the prokineticin 2 pathway [7]. Moreover, in murine models, metformin provided substantial protection against DC, reducing the production of ROS, expression of p53, and production of collagen [66].

In a clinical setting, in a retrospective cohort study on 242 adults with DMT2 undergoing coronary angiography, the use of metformin was associated with improved LV diastolic function (lower IVRT and higher $\mathrm{e}^{\prime}$ wave), as compared with sulfonylurea or insulin therapy [67]. Moreover, a 2-years prospective, randomized, open-label trial on 49 non-diabetic patients with metabolic syndrome and diastolic dysfunction showed that treatment with metformin (1000 mg bid) on top of lifestyle counseling was associated with significant improvement of diastolic function (improved $\mathrm{e}^{\prime}$ velocity and reduced insulin resistance) as compared with lifestyle counseling alone [68]. A meta-analysis of 13 trials conducted between 1995 and 2011 with a total of 2.079 individuals with DMT2 demonstrated that the use of metformin slightly improved the risk of all-cause mortality, cardiovascular death, myocardial infarction, and peripheral disease as compared with control strategies (no intervention, placebo, or lifestyle changes), but none of these outcomes achieved statistical significance [69].

\subsection{Sulfonylureas}

Sulfonylureas are a class of oral anti-diabetes agents that stimulate the release of insulin from pancreatic $\beta$ cells. In experimental murine models, triple anti-diabetes oral therapy with glimepiride, metformin, and rosiglitazone showed a synergistic effect in improving insulin resistance and retarding development of DC [70]. However, there is evidence that associates the use of sulfonylureas with a higher risk of hypoglycemia and weight gain [71], which in turn increases the risk of HF. Moreover, in a cohort study on new users of metformin or sulfonylurea in the veteran's population, the initiation of sulfonylurea was associated with a $32 \%$ increased risk of HF hospitalization and cardiovascular death compared with metformin initiation [72]. In a pooled analysis of clinical trials, the use of sulfonylureas did not significantly increase the risk of MACE, cardiovascular death, or HF hospitalization [73]. At the moment, sulfonylureas are not indicated as first-line treatment for patients with DMT2 and cardiovascular disease by international guidelines for the management of DMT2 [71]; therefore, their use should be considered in people free of CVD in case of intolerance to metformin or when an upgrade of glucose-lowering therapy is needed.

\subsection{Thiazolidinediones}

Thiazolidinediones are oral anti-hyperglycemic agents that act on peroxisome proliferatoractivated receptor- $\gamma$ (PPR- $\gamma$ ) to increase insulin sensitivity in peripheral tissues. Both clinical and experimental studies suggest beneficial effects of these molecules on inflammation, lipid and protein metabolism, and vascular endothelial function [74,75].

In preclinical studies on diabetic mice, the use of pioglitazone remarkably increased ventricular function, reduced fibrosis and TGF- $\beta$ protein expression in myocardial tissues, 
and attenuated myocardial hypertrophy [75]. Moreover, pioglitazone combined with curcumin reduced oxidative stress and fibrosis in diabetic rats, decreasing lipid peroxidation and TGF- $\beta 1$ level [76]. However, the use of these drugs in clinical practice is limited due to their potential to cause weight gain, edema, fractures, and HF. Indeed, the addition of pioglitazone and rosiglitazone in clinical trials demonstrated a significant increase in the risk for heart failure hospitalizations $[77,78]$. Therefore, these agents should be avoided in patients with HF and used with caution in patients who have any signs or symptoms of HF.

\subsection{SGLT-2 Inhibitors}

Sodium-glucose cotransporter 2 inhibitors (SGLT-2i) are the latest class of oral glucoselowering agents approved by FDA for management of DMT2. These drugs inhibit the renal sodium/glucose cotransporter in the kidney proximal convoluted tubule, increasing glycosuria and favoring osmotic diuresis [79].

Over the last few years, there has been a growing body of evidence from randomized controlled trials of their cardiovascular and renal benefits in people with DMT2 at high cardiovascular risk [80]. Although it is noticeable that SGLT-2i exert beneficial cardiovascular effects, the specific mechanisms of action of SGLT-2i on cardiac metabolism have not yet been carefully understood. The potential mechanisms involved in the cardiovascular protection are the glucose-lowering effect, weight loss, blood pressure reduction, hemodynamic effects, osmotic diuresis, and natriuresis. Conversely, SGLT-2 seems to not be expressed in cardiac myocytes [81]. However, SGLT-2i may have a direct action on the myocardium by the inhibition of the sodium-hydrogen exchanger (NHE), which may be involved in myocardial injury, fibrosis, and LV dysfunction [82].

In preclinical studies, dapagliflozin was demonstrated to reduce ROS production, decrease fibrosis, reduce inflammation, and improve systolic function in an experimental model of DC [83]. When added to ticagrelor, dapagliflozin ameliorated the progression of DC, attenuating the activation of NLRP3 inflammasome, and reducing TNF $\alpha$ and IL-6 levels and fibrosis [84]. The use of empagliflozin in diabetic mice for 8 weeks was associated with decreased myocardial oxidative stress, reduced myocardial fibrosis, and better myocardial structure and function [85]. Moreover, empagliflozin improved diastolic function and reduced mortality in a murine model of severe diabetes [86].

In a prospective observational study of 35 symptomatic non-ischemic HF patients with DMT2 and LVEF $>40 \%$ treated with empagliflozin (EMPA group) and 20 control subjects, patients in the empagliflozin group showed a significant improvement of LV dysfunction [LV global longitudinal strain (LVGLS) and the ratio of early diastolic mitral inflow velocity to early diastolic mitral annular velocity $\left(\mathrm{E} / \mathrm{e}^{\prime}\right)$ ], particularly in early cardiomyopathy stages [87]. Data from a meta-analysis of the CVOTs involving the use of SGLT2-i versus placebo show a significant 33\% reduced risk of hospitalization for $\mathrm{HF}$ in people using this class of drugs [73,88]. Since this effect is associated with each studied molecule (dapagliflozin, empagliflozin, canagliflozin, ertugliflozin, and sotagliflozin), the reduced risk for HF related to SGLT-2i should be considered a class effect [79]. Indeed, according to the Standards of Medical Care in Diabetes 2021 of the American Diabetes Association, a SGLT-2i with proven cardiovascular benefit is recommended as part of the glucose-lowering regimen, independent of $\mathrm{HbA1c}$, for patients with type 2 diabetes who have an established history of HF, and particularly with reduced ejection fraction (HFrEF, LVEF < 45\%) [71]. Thus, the use of SGLT2i should be recommended as soon as possible in patients with type 2 diabetes and HF at early stages.

\subsection{GLP-1 Receptor Agonists}

Glucagon-like peptide-1 receptor agonists (GLP-1RAs) are a class of injective antidiabetes agents that lower blood glucose levels, enhancing insulin secretion in response to nutrient ingestion, without risk of hypoglycemia. Moreover, they inhibit inappropriate glucagon secretion, suppress appetite, and slow gastric emptying, which represent all pleiotropic favorable effects in the management of DMT2 [89]. 
Over the years, GLP-1RAs have demonstrated many beneficial effects on the cardiovascular system. These agents may exert their benefits both indirectly by decreasing different established cardiovascular risk factors (hyperglycemia, obesity, high blood pressure, and lipid profile) and directly on cardiomyocytes and coronary vasculature [90]. The expression of GLP-1 receptor has been reported in human atrial tissue, vascular smooth muscles, and endothelial cells [91]. GLP-1RA seem to reduce inflammatory myocardial remodeling and decrease inflammatory pathways in cardiomyocytes, promoting glucose uptake and increasing coronary blood flow [90].

Exenatide, a short-acting glucagon-like peptide-1 (GLP-1) receptor agonist, has proven to attenuate ROS production, increasing the antioxidant enzymes manganese-dependent superoxide dismutase (MnSOD) and catalase activity and preventing cell apoptosis [92]. Treatment of lean mice with liraglutide showed to increase myocardial glucose oxidation, enhancing pyruvate dehydrogenase activity and alleviating diastolic dysfunction in mice with DMT2 [93]. In a preclinical study on streptozotocin-induced diabetic rats treated with liraglutide and/or empagliflozin, both agents were effective in ameliorating myocardial fibrosis and apoptosis. Particularly, empagliflozin modulated fatty acid and glucose metabolism, while liraglutide regulated inflammation and apoptosis in DC [94].

Whether GLP-1RAs are effective in improving ventricular function in human subjects is still controversial. A 5-week continuous subcutaneous infusion of GLP-1 $(2.5 \mathrm{pmol} / \mathrm{kg} / \mathrm{min}$ ) in 12 patients with New York Heart Association (NYHA) class III-IV HF significantly improved LV function, walking time, and quality of life scores in patients with severe HF [95]. However, the exciting results of the earlier pilot study were not completely confirmed in larger studies of GLP-1RA in patients with HF. Among 154 recently hospitalized patients with $\mathrm{HFrEF}$, the use of liraglutide did not lead to greater post-hospitalization clinical stability for HF as compared with placebo in a 6-months randomized controlled clinical trial [96]. On the other hand, in another randomized controlled trial of 49 subjects with DMT2 without cardiovascular disease assigned to liraglutide (1.8 mg once daily) or placebo, treatment with liraglutide for 6 months reduced early LV diastolic filling and LV filling pressure, thereby improving diastolic function [97].

In the randomized, double-blinded, placebo-controlled multicenter LIVE trial, 241 subjects with reduced LV ejection fraction ( $\mathrm{LVEF} \leq 45 \%)$ with and without diabetes were randomized to liraglutide or placebo [98]. As a result, liraglutide did not improve LV systolic function as compared with placebo in stable chronic heart failure patients and was rather associated with an increase in heart rate and more serious cardiac adverse events. However, a recent meta-analysis of the eight CVOTs with GLP-1RAs so far conducted, including 60,080 participants, demonstrated that GLP-1RAs reduced the risk of MACE by $14 \%$, the risk of cardiovascular death by $13 \%$, and the risk of hospitalization for HF by $10 \%$ [99].

Although this class of agents has been associated with potential benefits on the risk of HF, further studies are needed to specifically assess the efficacy of GLP-1RAs in the setting of DC.

\subsection{DPP-4 Inhibitors}

Dipeptidyl peptidase-4 inhibitor (DPP-4i) represents another new class of oral glucoselowering agents that block the enzyme DPP-4, thereby extending the lifetime of incretin hormones [GLP-1 and glucose-dependent insulinotropic polypeptide (GIP)] and enhancing insulin secretion in a glucose-dependent manner. Pre-clinical studies reported a correlation between DPP-4 activity and cardiac dysfunction [100], as well as the improvement of pump function with the use of DPP-4i [101].

In experimental murine models, sitagliptin showed to down-regulate the JAK/STAT signaling pathway-ameliorating histological cardiac structure, oxidative stress, and inflammation — and rejuvenated the antioxidant defenses in diabetic hearts [102]. Sitagliptin 
could also improve the contraction and relaxation functions of cardiomyocytes in diabetic rats [103].

In a small 24-weeks randomized trial, the use of sitagliptin in subjects with T2DM inadequately controlled with metformin and glyburide was associated with improvement in diastolic function as compared with NPH insulin [104]. Furthermore, an improvement of diastolic function reflected by attenuation of the increase in $\mathrm{E} / \mathrm{e}^{\prime}$ ratio was also observed with sitagliptin compared with placebo in a 24- months, randomized trial of 115 Japanese subjects with DMT2 whose blood glucose was inadequately controlled with lifestyle interventions and/or pharmacotherapy [105]. On the contrary, the use of sitagliptin at the dosage of $50 \mathrm{mg}$ once daily did not produce a significant effect on diastolic function in 80 subjects with DMT2 compared with voglibose ( $0.6 \mathrm{mg}$ once daily) in a 24-weeks randomized trial [106]. Despite these potential beneficial effects, data from the larger CVOTs with DPP-4i have resulted in a substantial non-inferiority versus placebo with respect to the risk of MACE. Moreover, some concerns have been raised on the possibility of a higher risk of HF hospitalization combined with the use of some molecules in specific trials. Indeed, in the SAVOR-TIMI trial, treatment with saxagliptin was associated with a $7 \%$ increased risk of HF hospitalization as compared with placebo [107]. A similar, although not statistically significant trend has been detected also in the EXAMINE trial with the use of alogliptin [108] and CAROLINA trial with linagliptin [109], whereas no difference was observed in the TECOS trial with sitagliptin [110].

However, in a recent umbrella meta-analysis, the use of DPP-4i was not associated with a significant increase in HF risk [73]. Thus, this effect seems to be drug-specific and imputable to the sole use of saxagliptin.

\subsection{Lipid-Lowering Therapy}

Drugs that lower plasma lipids seem to improve cardiac performance in diabetic rats. Statins are effective, pleiotropic lipid-lowering agents representing the first-line therapy for patients with diabetes and dyslipidemia and a cornerstone of prevention of CVD [111]. In previous animal experiments, statins were hypothesized to prevent DC by multiple pleiotropic properties, including anti-inflammatory and antioxidant effects [111]. Rosuvastatin reduced NLRP3 inflammasome and IL-1 $\beta$ activation by suppressing MAPK pathways in diabetic rats [112]. Simvastatin also exhibited protective effects by significantly reducing cardiac enzymes, inflammatory mediators, and deposition of collagen in the diabetic murine heart [113]. On the other hand, an 8-weeks study on 87 murine models with type 1 diabetes rather suggested that glycemic control was more important than pravastatin to attenuate the progression of DC, expressed as the cardiac expression of collagen I/III, matrix metalloproteinase (MMP)-2, MMP-9, and angiotensin-converting enzyme (ACE) [114]. Atorvastatin was able to preserve the myocardial structure, inhibiting fibrosis through anti-apoptosis and anti-inflammation pathways [115]. Atorvastatin could also reduce $\beta$-adrenergic dysfunction in rats with diabetic cardiomyopathy via increasing NO availability [116]. Recently, the combined administration of metformin and atorvastatin in experimental models significantly inhibited oxidative stress and the levels of inflammation-related proteins, [NLRP3, caspase-1, interleukin-1 $\beta$ (IL-1 $\beta$ ), Toll-like receptor 4 (TLR4)], decreased pro-apoptotic-related proteins (cleaved caspase-3 and BAX), and increased anti-apoptotic proteins (Bcl-2) [117]. Also fenofibrate, which is a peroxisome proliferator-activated receptor $\alpha($ PPAR $\alpha)$ agonist, prevented heart damage in the wild-type 1 diabetic mice by reducing inflammation and fibrosis in cardiomyocytes [118].

The effects of lipid-lowering therapy in the clinical setting are still unknown. However, the use of statins is associated with an important decrease of cardiovascular risk in diabetic patients also in primary prevention [119]. Indeed, international guidelines suggest statins together with other lipid-lowering agents (PPAR $\alpha$ agonists) for both primary and secondary CV prevention [120]. 


\section{Conclusions}

Although DC is rarely clinically evident, particularly in its early phase, it is a common condition, which increases the risk of the development of HF in people with diabetes. Its pathogenesis is still not completely clarified, although hyperglycemia, cardiac insulin resistance, and inflammatory pathways are key factors for myocardial fibrosis, stiffness, and hypertrophy. Achieving optimal glycemic control is important to prevent and delay diabetes complications and preserve heart health. Changes in lifestyle favoring healthy dietary patterns and physical activity, combined with more innovative anti-diabetes therapies are the current treatment strategies to safeguard the cardiovascular system. Data from randomized controlled trials show that both SGLT-2i and GLP-1RA offer protection against major cardiovascular events, including CV mortality and hospitalization for $\mathrm{HF}$, in people with DMT2 at high CV risk. Future and larger studies are needed to better clarify the pathogenic mechanisms of pump dysfunction in diabetes and the effects of innovative therapies on DC and systolic and diastolic dysfunction.

Author Contributions: M.L. and L.S. conceived the review and wrote the manuscript. P.C., A.M. and R.C. collected the data for the work. M.I.M., G.B. and K.E. reviewed and critiqued the manuscript. All authors have read and agreed to the published version of the manuscript.

Funding: This research received no external funding.

Institutional Review Board Statement: Not applicable.

Informed Consent Statement: Not applicable.

Conflicts of Interest: The authors declare no conflict of interest.

\section{References}

1. American Diabetes Association. 10. Cardiovascular Disease and Risk Management: Standards of Medical Care in Diabetes-2021. Diabetes Care 2021, 44, S125-S150. [CrossRef] [PubMed]

2. Giugliano, D.; Bellastella, G.; Longo, M.; Scappaticcio, L.; Maiorino, M.I.; Chiodini, P.; Esposito, K. Relationship between improvement of glycaemic control and reduction of major cardiovascular events in 15 cardiovascular outcome trials: A metaanalysis with meta-regression. Diabetes Obes. Metab. 2020, 22, 1397-1405. [CrossRef] [PubMed]

3. Seferović, P.M.; Petrie, M.C.; Filippatos, G.S.; Anker, S.D.; Rosano, G.; Bauersachs, J.; Paulus, W.J.; Komajda, M.; Cosentino, F.; de Boer, R.A.; et al. Type 2 diabetes mellitus and heart failure: A position statement from the Heart Failure Association of the European Society of Cardiology. Eur. J. Heart Fail. 2018, 20, 853-872. [CrossRef] [PubMed]

4. Lee, M.; McMurray, J.; Lorenzo-Almorós, A.; Kristensen, S.L.; Sattar, N.; Jhund, P.S.; Petrie, M.C. Diabetic cardiomyo-pathy. Heart 2019, 105, 337-345. [CrossRef] [PubMed]

5. Hölscher, M.E.; Bode, C.; Bugger, H. Diabetic Cardiomyopathy: Does the Type of Diabetes Matter? Int. J. Mol. Sci. 2016, 17, 2136. [CrossRef] [PubMed]

6. Konduracka, E.; Cieslik, G.; Galicka-Latala, D.; Rostoff, P.; Pietrucha, A.; Latacz, P.; Gajos, G.; Malecki, M.T.; Nessler, J. Myocardial dysfunction and chronic heart failure in patients with long-lasting type 1 diabetes: A 7-year prospective cohort study. Acta Diabetol. 2013, 50, 597-606. [CrossRef]

7. Murtaza, G.; Virk, H.; Khalid, M.; Lavie, C.J.; Ventura, H.; Mukherjee, D.; Ramu, V.; Bhogal, S.; Kumar, G.; Shanmu-gasundaram, M.; et al. Diabetic cardiomyopathy-A comprehensive updated review. Prog. Cardiovasc. Dis. 2019, 62, 315-326. [CrossRef]

8. Fang, Z.Y.; Prins, J.B.; Marwick, T.H. Diabetic cardiomyopathy: Evidence, mechanisms, and therapeutic implications. Endocr. Rev. 2004, 25, 543-567. [CrossRef]

9. Maisch, B.; Alter, P.; Pankuweit, S. Diabetic cardiomyopathy-Fact or fiction? Herz 2011, 36, 102-115. [CrossRef]

10. Seferović, P.M.; Paulus, W.J. Clinical diabetic cardiomyopathy: A two-faced disease with restrictive and dilated pheno-types. Eur. Heart J. 2015, 36, 1718-1727. [CrossRef]

11. Di Bonito, P.; Moio, N.; Cavuto, L.; Covino, G.; Murena, E.; Scilla, C.; Turco, S.; Capaldo, B.; Sibilio, G. Early detection of diabetic cardiomyopathy: Usefulness of tissue Doppler imaging. Diabet. Med. 2005, 22, 1720-1725. [CrossRef]

12. Kwong, R.Y.; Sattar, H.; Wu, H.; Vorobiof, G.; Gandla, V.; Steel, K.; Siu, S.; Brown, K.A. Incidence and prognostic im-plication of unrecognized myocardial scar characterized by cardiac magnetic resonance in diabetic patients without clinical evidence of myocardial infarction. Circulation 2008, 118, 1011-1020. [CrossRef]

13. Pofi, R.; Giannetta, E.; Galea, N.; Francone, M.; Campolo, F.; Barbagallo, F.; Gianfrilli, D.; Venneri, M.A.; Filardi, T.; Cristini, C.; et al. Diabetic Cardiomiopathy Progression is Triggered by miR122-5p and Involves Extracellular Matrix: A 5-Year Prospective Study. JACC Cardiovasc. Imaging 2021, 14, 1130-1142. [CrossRef] 
14. Maisel, A.S.; Koon, J.; Krishnaswamy, P.; Kazenegra, R.; Clopton, P.; Gardetto, N.; Morrisey, R.; Garcia, A.; Chiu, A.; De Maria, A. Utility of B-natriuretic peptide as a rapid, point-of-care test for screening patients undergoing echocardiography to determine left ventricular dysfunction. Am. Heart J. 2001, 141, 367-374. [CrossRef]

15. Swoboda, P.P.; McDiarmid, A.K.; Erhayiem, B.; Ripley, D.P.; Dobson, L.E.; Garg, P.; Musa, T.A.; Witte, K.K.; Kearney, M.T.; Barth, J.H.; et al. Diabetes Mellitus, Microalbuminuria, and Subclinical Cardiac Disease: Identification and Monitoring of Individ-uals at Risk of Heart Failure. J. Am. Heart Assoc. 2017, 6, e005539. [CrossRef]

16. Ritchie, R.H.; Abel, E.D. Basic Mechanisms of Diabetic Heart Disease. Circ. Res. 2020, 126, 1501-1525. [CrossRef]

17. Jia, J.; Hill, M.A.; Sowers, J.R. Diabetic Cardiomyopathy: An Update of Mechanisms Contributing to This Clinical Entity. Circ. Res. 2018, 122, 624-638. [CrossRef]

18. Falcão-Pires, I.; Leite-Moreira, A.F. Diabetic cardiomyopathy: Understanding the molecular and cellular basis to progress in diagnosis and treatment. Heart Fail. Rev. 2012, 17, 325-344. [CrossRef]

19. Heather, L.C.; Clarke, K. Metabolism, hypoxia and the diabetic heart. J. Mol. Cell Cardiol. 2011, 50, 598-605. [CrossRef]

20. Taegtmeyer, H. Cardiac metabolism as a target for the treatment of heart failure. Circulation 2004, 110, 894-896. [CrossRef]

21. Park, S.; Jeon, J.H.; Min, B.K.; Ha, C.M.; Thoudam, T.; Park, B.Y.; Lee, I.K. Role of the Pyruvate Dehydrogenase Complex in Metabolic Remodeling: Differential Pyruvate Dehydrogenase Complex Functions in Metabolism. Diabetes Metab. J. 2018, 42, 270-281. [CrossRef]

22. Karwi, Q.G.; Wagg, C.S.; Altamimi, T.R.; Uddin, G.M.; Ho, K.L.; Darwesh, A.M.; Seubert, J.M.; Lopaschuk, G.D. Insulin directly stimulates mitochondrial glucose oxidation in the heart. Cardiovasc. Diabetol. 2020, 19, 207. [CrossRef]

23. Badolia, R.; Ramadurai, D.; Abel, E.D.; Ferrin, P.; Taleb, I.; Shankar, T.S.; Krokidi, A.T.; Navankasattusas, S.; McKellar, S.H.; Yin, M.; et al. The Role of Nonglycolytic Glucose Metabolism in Myocardial Recovery Upon Mechanical Unloading and Circulatory Support in Chronic Heart Failure. Circulation 2020, 142, 259-274. [CrossRef]

24. Diakos, N.A.; Navankasattusas, S.; Abel, E.D.; Rutter, J.; McCreath, L.; Ferrin, P.; McKellar, S.H.; Miller, D.V.; Park, S.Y.; Richardson, R.S.; et al. Evidence of Glycolysis Up-Regulation and Pyruvate Mitochondrial Oxidation Mismatch During Mechanical Unloading of the Failing Human Heart: Implications for Cardiac eloading and Conditioning. JACC Basic Transl. Sci. 2016, 1, 432-444. [CrossRef]

25. Young, M.E.; McNulty, P.; Taegtmeyer, H. Adaptation and maladaptation of the heart in diabetes: Part II: Potential mechanisms. Circulation 2002, 105, 1861-1870. [CrossRef]

26. Zhong, Y.; Ahmed, S.; Grupp, I.L.; Matlib, M.A. Altered SR protein expression associated with contractile dysfunction in diabetic rat hearts. Am. J. Physiol. Heart Circ. Physiol. 2001, 281, H1137-H1147. [CrossRef]

27. Lacombe, V.A.; Viatchenko-Karpinski, S.; Terentyev, D.; Sridhar, A.; Emani, S.; Bonagura, J.D.; Feldman, D.S.; Györke, S.; Carnes, C.A. Mechanisms of impaired calcium handling underlying subclinical diastolic dysfunction in diabetes. Am. J. Physiol. Regul. Integr. Comp. Physiol. 2007, 293, R1787-R1797. [CrossRef]

28. Kaiser, N.; Leibowitz, G.; Nesher, R. Glucotoxicity and beta-cell failure in type 2 diabetes mellitus. J. Pediatr. Endocrinol. Metab. 2003, 16, 5-22. [CrossRef]

29. Parhofer, K.G. Interaction between Glucose and Lipid Metabolism: More than Diabetic Dyslipidemia. Diabetes Metab. J. 2015, 39, 353-362. [CrossRef]

30. Kozakova, M.; Morizzo, C.; Goncalves, I.; Natali, A.; Nilsson, J.; Palombo, C. Cardiovascular organ damage in type 2 diabetes mellitus: The role of lipids and inflammation. Cardiovasc. Diabetol. 2019, 18, 61. [CrossRef]

31. Costantino, S.; Akhmedov, A.; Melina, G.; Mohammed, S.A.; Othman, A.; Ambrosini, S.; Wijnen, W.J.; Sada, L.; Ciavarella, G.M.; Liberale, L.; et al. Obesity-induced activation of JunD promotes myocardial lipid accumulation and metabolic cardiomyopathy. Eur. Heart J. 2019, 40, 997-1008. [CrossRef]

32. Wang, L.; Cai, Y.; Jian, L.; Cheung, C.W.; Zhang, L.; Xia, Z. Impact of peroxisome proliferator-activated receptor- $\alpha$ on diabetic cardiomyopathy. Cardiovasc. Diabetol. 2021, 20, 2. [CrossRef]

33. Jia, G.; DeMarco, V.G.; Sowers, J.R. Insulin resistance and hyperinsulinaemia in diabetic cardiomyopathy. Nat. Rev. Endocrinol. 2016, 12, 144-153. [CrossRef]

34. Lee, T.W.; Bai, K.J.; Lee, T.I.; Chao, T.F.; Kao, Y.H.; Chen, Y.J. PPARs modulate cardiac metabolism and mitochondrial function in diabetes. J. Biomed. Sci. 2017, 24, 5. [CrossRef]

35. Harmancey, R.; Lam, T.N.; Lubrano, G.M.; Guthrie, P.H.; Vela, D.; Taegtmeyer, H. Insulin resistance improves metabolic and contractile efficiency in stressed rat heart. FASEB J. Off. Publ. Fed. Am. Soc. Exp. Biol. 2012, 26, 3118-3126. [CrossRef]

36. Mandavia, C.H.; Pulakat, L.; DeMarco, V.; Sowers, J.R. Over-nutrition and metabolic cardiomyopathy. Metabolism 2012, 61, 1205-1210. [CrossRef]

37. Habets, D.D.; Coumans, W.A.; Voshol, P.J.; den Boer, M.A.; Febbraio, M.; Bonen, A.; Glatz, J.F.; Luiken, J.J. AMPK-mediated increase in myocardial long-chain fatty acid uptake critically depends on sarcolemmal CD36. Biochem. Biophys. Res. Commun. 2007, 355, 204-210. [CrossRef]

38. Yang, J.; Sambandam, N.; Han, X.; Gross, R.W.; Courtois, M.; Kovacs, A.; Febbraio, M.; Finck, B.N.; Kelly, D.P. CD36 deficiency rescues lipotoxic cardiomyopathy. Circ. Res. 2007, 100, 1208-1217. [CrossRef]

39. Tanaka, T.; Nakata, T.; Oka, T.; Ogawa, T.; Okamoto, F.; Kusaka, Y.; Sohmiya, K.; Shimamoto, K.; Itakura, K. Defect in human myocardial long-chain fatty acid uptake is caused by FAT/CD36 mutations. J. Lipid Res. 2001, 42, 751-759. [CrossRef] 
40. Faria, A.; Persaud, S.J. Cardiac oxidative stress in diabetes: Mechanisms and therapeutic potential. Pharmacol. Ther. 2017, 172, 50-62. [CrossRef]

41. Wilson, A.J.; Gill, E.K.; Abudalo, R.A.; Edgar, K.S.; Watson, C.J.; Grieve, D.J. Reactive oxygen species signalling in the diabetic heart: Emerging prospect for therapeutic targeting. Heart 2018, 104, 293-299. [CrossRef] [PubMed]

42. Biernacka, A.; Cavalera, M.; Wang, J.; Russo, I.; Shinde, A.; Kong, P.; Gonzalez-Quesada, C.; Rai, V.; Dobaczewski, M.; Lee, D.W.; et al. Smad3 Signaling Promotes Fibrosis While Preserving Cardiac and Aortic Geometry in Obese Diabetic Mice. Circulation 2015, 8, 788-798. [CrossRef]

43. Maruhashi, T.; Higashi, Y. Pathophysiological Association between Diabetes Mellitus and Endothelial Dysfunction. Antioxidants 2021, 10, 1306. [CrossRef]

44. Geraldes, P.; King, G.L. Activation of protein kinase C isoforms and its impact on diabetic complications. Circ. Res. 2010, 106, 1319-1331. [CrossRef]

45. Rask-Madsen, C.; King, G.L. Vascular complications of diabetes: Mechanisms of injury and protective factors. Cell Metab. 2013, 17, 20-33. [CrossRef]

46. Yuan, T.; Yang, T.; Chen, H.; Fu, D.; Hu, Y.; Wang, J.; Yuan, Q.; Yu, H.; Xu, W.; Xie, X. New Insights into Oxidative Stress and Inflammation during Diabetes Mellitus-Accelerated Atherosclerosis. Redox Biol. 2019, 20, 247-260. [CrossRef]

47. Lien, C.F.; Chen, S.J.; Tsai, M.C.; Lin, C.S. Potential Role of Protein Kinase C in the Pathophysiology of Diabetes-Associated Atherosclerosis. Front. Pharmacol. 2021, 12, 716332. [CrossRef]

48. Fuentes-Antras, J.; Ioan, A.M.; Tunon, J.; Egido, J.; Lorenzo, O. Activation of Toll-like repceptors and inflammasome complexes in the diabetic cardiomyopathy-associated inflammation. Int. J. Endocrinol. 2014, 2014, 847827. [CrossRef]

49. Pal, P.B.; Sonowal, H.; Shukla, K.; Srivastava, S.K.; Ramana, K.V. Aldose reductase mediates NLRP3 inflammasome-initiated innate immune response in hyperglycemia-induced Thp1 monocytes and male mice. Endocrinology 2017, 158, 3661-3675. [CrossRef]

50. Giacco, F.; Brownlee, M. Oxidative stress and diabetic complications. Circ. Res. 2010, 107, 1058-1070. [CrossRef]

51. Bodiga, V.L.; Eda, S.R.; Bodiga, S. Advanced glycation end products: Role in pathology of diabetic cardiomyopathy. Heart Fail. Rev. 2014, 19, 49-63. [CrossRef] [PubMed]

52. Ma, H.; Li, S.Y.; Xu, P.; Babcock, S.A.; Dolence, E.K.; Brownlee, M.; Li, J.; Ren, J. Advanced glycation endproduct (AGE) accumulation and AGE receptor (RAGE) up-regulation contribute to the onset of diabetic cardiomyopathy. J. Cell Mol. Med. 2009, 13, 1751-1764. [CrossRef] [PubMed]

53. Papachristoforou, E.; Lambadiari, V.; Maratou, E.; Makrilakis, K. Association of Glycemic Indices (Hyperglycemia, Glucose Variability, and Hypoglycemia) with Oxidative Stress and Diabetic Complications. J. Diabetes Res. 2020, 2020, 7489795. [CrossRef]

54. Verrotti, A.; Prezioso, G.; Scattoni, R.; Chiarelli, F. Autonomic neuropathy in diabetes mellitus. Front. Endocrinol. 2014, 5, 205. [CrossRef]

55. Bernardi, S.; Michelli, A.; Zuolo, G.; Candido, R.; Fabris, B. Update on RAAS Modulation for the Treatment of Diabetic Cardiovascular Disease. J. Diabetes Res. 2016, 2016, 8917578. [CrossRef]

56. Mozaffarian, D.; Benjamin, E.J.; Go, A.S.; Arnett, D.K.; Blaha, M.J.; Cushman, M.; de Ferranti, S.; Despres, J.P.; Fullerton, H.J.; Howard, V.J.; et al. American Heart Association Statistics Committee and Stroke Statistics Subcommittee. Heart disease and stroke statistics: 2015 update: A report from the American Heart Association. Circulation 2015, 131, e29-e322. [PubMed]

57. Iribarren, C.; Karter, A.J.; Go, A.S.; Ferrara, A.; Liu, J.Y.; Sidney, S.; Selby, J.V. Glycemic control and heart failure among adult patients with diabetes. Circulation 2001, 103, 2668-2673. [CrossRef]

58. Zhou, F.L.; Deng, M.Y.; Deng, L.L.; Li, Y.M.; Mo, D.; Xie, L.J.; Gao, Y.; Tian, H.M.; Guo, Y.K.; Ren, Y. Evaluation of the effects of glycated hemoglobin on cardiac function in patients with short-duration type 2 diabetes mellitus: A cardiovascular magnetic resonance study. Diabetes Res. Clin. Pract. 2021, 178, 108952. [CrossRef]

59. Lee, S.; Liu, T.; Zhou, J.; Zhang, Q.; Wong, W.T.; Tse, G. Predictions of diabetes complications and mortality using hba1c variability: A 10-year observational cohort study. Acta Diabetol. 2021, 58, 171-180. [CrossRef]

60. Schrauwen-Hinderling, V.B.; Meex, R.C.; Hesselink, M.K.; van de Weijer, T.; Leiner, T.; Schär, M.; Lamb, H.J.; Wildberger, J.E.; Glatz, J.F.; Schrauwen, P.; et al. Cardiac lipid content is unresponsive to a physical activity training intervention in type 2 diabetic patients, despite improved ejection fraction. Cardiovasc. Diabetol. 2011, 10, 47. [CrossRef]

61. Longo, M.; Scappaticcio, L.; Caputo, M.; Maiorino, M.I.; Esposito, K. Mediterranean diet in type 2 diabetes: An updated overview of pharmacological activities of cardiometabolic and reproductive outcomes. Curr. Opin. Pharmacol. 2021, 60, 27-33. [CrossRef] [PubMed]

62. Maiuolo, J.; Carresi, C.; Gliozzi, M.; Musolino, V.; Scarano, F.; Coppoletta, A.R.; Guarnieri, L.; Nucera, S.; Scicchitano, M.; Bosco, F.; et al. Effects of Bergamot Polyphenols on Mitochondrial Dysfunction and Sarcoplasmic Reticulum Stress in Diabetic Cardiomyopathy. Nutrients 2021, 13, 2476. [CrossRef] [PubMed]

63. Strengers, J.G.; den Ruijter, H.M.; Boer, J.M.A.; Asselbergs, F.W.; Verschuren, W.M.M.; van der Schouw, Y.T.; Sluijs, I. The association of the Mediterranean diet with heart failure risk in a Dutch population. Nutr. Metab. Cardiovasc. Dis. 2021, 31, 60-66. [CrossRef] [PubMed]

64. Eurich, D.T.; McAlister, F.A.; Blackburn, D.F.; Majumdar, S.R.; Tsuyuki, R.T.; Varney, J.; Johnson, J.A. Benefits and harms of antidiabetic agents in patients with diabetes and heart failure: Systematic review. BMJ 2007, 335, 497. [CrossRef]

65. Wang, X.F.; Zhang, J.Y.; Li, L.; Zhao, X.Y.; Tao, H.L.; Zhang, L. Metformin improves cardiac function in rats via activation of AMP-activated protein kinase. Clin. Exp. Pharm. Physiol. 2011, 38, 94-101. [CrossRef] [PubMed] 
66. Yang, Z.; Wang, M.; Zhang, Y.; Cai, F.; Jiang, B.; Zha, W.; Yu, W. Metformin Ameliorates Diabetic Cardiomyopathy by Activating the PK2/PKR Pathway. Front. Physiol. 2020, 11. [CrossRef]

67. Andersson, C.; Søgaard, P.; Hoffmann, S.; Hansen, P.R.; Vaag, A.; Major-Pedersen, A.; Hansen, T.F.; Bech, J.; Køber, L.; TorpPedersen, C.; et al. Metformin is associated with improved left ventricular diastolic function measured by tissue Doppler imaging in patients with diabetes. Eur. J. Endocrinol. 2010, 163, 593-599. [CrossRef]

68. Ladeiras-Lopes, R.; Sampaio, F.; Leite, S.; Santos-Ferreira, D.; Vilela, E.; Leite-Moreira, A.; Bettencourt, N.; Gama, V.; Braga, P.; Fontes-Carvalho, R. Metformin in non-diabetic patients with metabolic syndrome and diastolic dysfunction: The MET-DIME randomized trial. Endocrine 2021, 72, 699-710. [CrossRef]

69. Griffin, S.J.; Leaver, J.K.; Irving, G.J. Impact of metformin on cardiovascular disease: A meta-analysis of randomised trials among people with type 2 diabetes. Diabetologia 2017, 60, 1620-1629. [CrossRef]

70. Sharma, A.K.; Srinivasan, B.P. Triple verses glimepiride plus metformin therapy on cardiovascular risk biomarkers and diabetic cardiomyopathy in insulin resistance type 2 diabetes mellitus rats. Eur. J. Pharm. Sci. 2009, 38, 433-444. [CrossRef]

71. American Diabetes Association. 9. Pharmacologic Approaches to Glycemic Treatment: Standards of Medical Care in Diabetes2021. Diabetes Care 2021, 44, S111-S124. [CrossRef] [PubMed]

72. Roumie, C.L.; Min, J.Y.; D'Agostino McGowan, L.; Presley, C.; Grijalva, C.G.; Hackstadt, A.J.; Hung, A.M.; Greevy, R.A.; Elasy, T.; Griffin, M.R. Comparative Safety of Sulfonylurea and Metformin Monotherapy on the Risk of Heart Failure: A Cohort Study. J. Am. Heart Assoc. 2017, 6, e005379. [CrossRef] [PubMed]

73. Zhu, J.; Yu, X.; Zheng, Y.; Li, J.; Wang, Y.; Lin, Y.; He, Z.; Zhao, W.; Chen, C.; Qiu, K.; et al. Association of glucose-lowering medications with cardiovascular outcomes: An umbrella review and evidence map. Lancet Diabetes Endocrinol. 2020, 8, 192-205. [CrossRef]

74. Campia, U.; Matuskey, L.A.; Panza, J.A. Peroxisome proliferator-activated receptor-gamma activation with pioglitazone improves endothelium-dependent dilation in nondiabetic patients with major cardiovascular risk factors. Circulation 2006, 113, 867-875 [CrossRef] [PubMed]

75. Zhang, X.D.; Sun, G.X.; Guo, J.J.; Hu, C.C.; Sun, R.C.; Yu, H.C. Effects of PPAR $\gamma$ agonist pioglitazone on cardiac fibrosis in diabetic mice by regulating PTEN/AKT/FAK pathway. Eur. Rev. Med. Pharmacol. Sci. 2021, 25, 812-819. [PubMed]

76. Gbr, A.A.; Abdel Baky, N.A.; Mohamed, E.A.; Zaky, H.S. Cardioprotective effect of pioglitazone and curcumin against diabetic cardiomyopathy in type 1 diabetes mellitus: Impact on CaMKII/NF-кB/TGF- $\beta 1$ and PPAR- $\gamma$ signaling pathway. NaunynSchmiedeberg's Arch. Pharmacol. 2021, 394, 349-360. [CrossRef] [PubMed]

77. Dormandy, J.A.; Charbonnel, B.; Eckland, D.J.; Erdmann, E.; Massi-Benedetti, M.; Moules, I.K.; Skene, A.M.; Tan, M.H.; Lefèbvre, P.J.; Murray, G.D.; et al. PROactive Investigators. Secondary prevention of macrovascular events in patients with type 2 diabetes in the PROactive Study (PROspective pioglitAzone Clinical Trial In macroVascular Events): A randomised controlled trial. Lancet 2005, 366, 1279-1289. [CrossRef]

78. Home, P.D.; Pocock, S.J.; Beck-Nielsen, H.; Curtis, P.S.; Gomis, R.; Hanefeld, M.; Jones, N.P.; Komajda, M.; McMurray, J.J.; RECORD Study Team. Rosiglitazone evaluated for cardiovascular outcomes in oral agent combination therapy for type 2 diabetes (RECORD): A multicentre, randomised, open-label trial. Lancet 2009, 373, 2125-2135. [CrossRef]

79. Giugliano, D.; Longo, M.; Scappaticcio, L.; Caruso, P.; Esposito, K. Sodium-glucose transporter-2 inhibitors for prevention and treatment of cardiorenal complications of type 2 diabetes. Cardiovasc. Diabetol. 2021, 20, 17. [CrossRef]

80. Giugliano, D.; Longo, M.; Caruso, P.; Maiorino, M.I.; Bellastella, G.; Esposito, K. Sodium-glucose co-transporter-2 inhibitors for the prevention of cardiorenal outcomes in type 2 diabetes: An updated meta-analysis. Diabetes Obes. Metab. 2021, 23, 1672-1676. [CrossRef]

81. Chen, J.; Williams, S.; Ho, S.; Loraine, H.; Hagan, D.; Whaley, J.M.; Feder, J.N. Quantitative PCR tissue expression profiling of the human SGLT2 gene and related family members. Diabetes Ther. 2010, 1, 57-92. [CrossRef]

82. Packer, M.; Anker, S.D.; Butler, J.; Filippatos, G.; Zannad, F. Effects of Sodium-Glucose Cotransporter 2 Inhibitors for the Treatment of Patients With Heart Failure: Proposal of a Novel Mechanism of Action. JAMA Cardiol. 2017, 2, 1025-1029. [CrossRef]

83. Arow, M.; Waldman, M.; Yadin, D.; Nudelman, V.; Shainberg, A.; Abraham, N.G.; Freimark, D.; Kornowski, R.; Aravot, D.; Hochhauser, E.; et al. Sodium-glucose cotransporter 2 inhibitor Dapagliflozin attenuates diabetic cardiomyopathy. Cardiovasc. Diabetol. 2020, 19, 7. [CrossRef] [PubMed]

84. Chen, H.; Tran, D.; Yang, H.C.; Nylander, S.; Birnbaum, Y.; Ye, Y. Dapagliflozin and Ticagrelor Have Additive Effects on the Attenuation of the Activation of the NLRP3 Inflammasome and the Progression of Diabetic Cardiomyopathy: An AMPK-mTOR Interplay. Cardiovasc. Drugs Ther. 2020, 34, 443-461. [CrossRef] [PubMed]

85. Li, C.; Zhang, J.; Xue, M.; Li, X.; Han, F.; Liu, X.; Xu, L.; Lu, Y.; Cheng, Y.; Li, T.; et al. SGLT2 inhibition with empagliflozin attenuates myocardial oxidative stress and fibrosis in diabetic mice heart. Cardiovasc. Diabetol. 2019, 18, 15. [CrossRef] [PubMed]

86. Moellmann, J.; Klinkhammer, B.M.; Droste, P.; Kappel, B.; Haj-Yehia, E.; Maxeiner, S.; Artati, A.; Adamski, J.; Boor, P.; Schütt, K.; et al. Empagliflozin improves left ventricular diastolic function of $\mathrm{db} / \mathrm{db}$ mice. Biochim. Biophys. Acta (BBA) Mol. Basis Dis. 2020, 1866, 165807. [CrossRef] [PubMed]

87. Oka, S.; Kai, T.; Hoshino, K.; Watanabe, K.; Nakamura, J.; Abe, M.; Watanabe, A. Effects of empagliflozin in different phases of diabetes mellitus-related cardiomyopathy: A prospective observational study. BMC Cardiovasc. Disord. 2021, 21, 217. [CrossRef]

88. Giugliano, D.; Maiorino, M.I.; Bellastella, G.; Esposito, K. The residual cardiorenal risk in type 2 diabetes. Cardiovasc. Diabetol. 2021, 20, 36. [CrossRef] 
89. Campbell, J.E.; Drucker, D.J. Pharmacology, physiology, and mechanisms of incretin hormone action. Cell Metab. 2013, 17, 819-837. [CrossRef]

90. Drucker, D.J. The Cardiovascular Biology of Glucagon-like Peptide-1. Cell Metab. 2016, 24, 15-30. [CrossRef]

91. Baggio, L.L.; Yusta, B.; Mulvihill, E.E.; Cao, X.; Streutker, C.J.; Butany, J.; Cappola, T.P.; Margulies, K.B.; Drucker, D.J. GLP-1 Receptor Expression Within the Human Heart. Endocrinology 2018, 159, 1570-1584. [CrossRef] [PubMed]

92. Ding, W.; Chang, W.G.; Guo, X.C.; Liu, Y.; Xiao, D.D.; Ding, D.; Wang, J.X.; Zhang, X.J. Exenatide Protects Against Cardiac Dysfunction by Attenuating Oxidative Stress in the Diabetic Mouse Heart. Front. Endocrinol. 2019, 10, 202. [CrossRef] [PubMed]

93. Almutairi, M.; Gopal, K.; Greenwell, A.A.; Young, A.; Gill, R.; Aburasayn, H.; Al Batran, R.; Chahade, J.J.; Manoj Gandhi, M.; Eaton, F.; et al. The GLP-1 Receptor Agonist Liraglutide Increases Myocardial Glucose Oxidation Rates via Indirect Mechanisms and Mitigates Experimental Diabetic Cardiomyopathy. Can. J. Cardiol. 2021, 37, 140-150. [CrossRef] [PubMed]

94. Trang, N.N.; Chung, C.C.; Lee, T.W.; Cheng, W.L.; Kao, Y.H.; Huang, S.Y.; Lee, T.I.; Chen, Y.J. Empagliflozin and Liraglutide Differentially Modulate Cardiac Metabolism in Diabetic Cardiomyopathy in Rats. Int. J. Mol. Sci. 2021, 22, 1177. [CrossRef] [PubMed]

95. Sokos, G.G.; Nikolaidis, L.A.; Mankad, S.; Elahi, D.; Shannon, R.P. Glucagon-like peptide-1 infusion improves left ventricular ejection fraction and functional status in patients with chronic heart failure. J. Card. Fail 2006, 12, 694-699. [CrossRef]

96. Margulies, K.B.; Hernandez, A.F.; Redfield, M.M.; Givertz, M.M.; Oliveira, G.H.; Cole, R.; Mann, D.L.; Whellan, D.J.; Kiernan, M.S.; Felker, G.M.; et al. NHLBI, Heart Failure Clinical Research Network. Effects of Liraglutide on Clinical Stability Among Patients With Advanced Heart Failure and Reduced Ejection Fraction: A Randomized Clinical Trial. JAMA 2016, 316, 500-508. [CrossRef]

97. Bizino, M.B.; Jazet, I.M.; Westenberg, J.J.M.; van Eyk, H.J.; Paiman, E.H.M.; Smit, J.W.A.; Lamb, H.J. Effect of liraglutide on cardiac function in patients with type 2 diabetes mellitus: Randomized placebo-controlled trial. Cardiovasc. Diabetol. 2019, 18, 55, Erratum in Cardiovasc. Diabetol. 2019, 18, 101. [CrossRef]

98. Jorsal, A.; Kistorp, C.; Holmager, P.; Tougaard, R.S.; Nielsen, R.; Hänselmann, A.; Nilsson, B.; Møller, J.E.; Hjort, J.; Rasmussen, J.; et al. Effect of liraglutide, a glucagon-like peptide-1 analogue, on left ventricular function in stable chronic heart failure patients with and without diabetes (LIVE)-a multicentre, double-blind, randomised, placebo-controlled trial. Eur. J. Heart Fail. 2017, 19, 69-77. [CrossRef]

99. Maiorino, M.I.; Longo, M.; Scappaticcio, L.; Bellastella, G.; Chiodini, P.; Esposito, K.; Giugliano, D. Improvement of glycemic control and reduction of major cardiovascular events in 18 cardiovascular outcome trials: An updated meta-regression. Cardiovasc. Diabetol. 2021, 20, 210. [CrossRef]

100. Dos Santos, L.; Salles, T.A.; Arruda-Junior, D.F.; Campos, L.C.; Pereira, A.C.; Barreto, A.L.; Antonio, E.L.; Mansur, A.J.; Tucci, P.J.; Krieger, J.E.; et al. Circulating dipeptidyl peptidase IV activity correlates with cardiac dysfunction in human and experimental heart failure. Circ. Heart Fail 2013, 6, 1029-1038. [CrossRef]

101. Suda, M.; Shimizu, I.; Yoshida, Y.; Hayashi, Y.; Ikegami, R.; Katsuumi, G.; Wakasugi, T.; Yoshida, Y.; Okuda, S.; Soga, T.; et al Inhibition of dipeptidyl peptidase-4 ameliorates cardiac ischemia and systolic dysfunction by up-regulating the FGF-2/EGR-1 pathway. PLoS ONE 2017, 12, e0182422. [CrossRef]

102. Al-Rasheed, N.M.; Al-Rasheed, N.M.; Hasan, I.H.; Al-Amin, M.A.; Al-Ajmi, H.N.; Mahmoud, A.M. Sitagliptin attenuates cardiomyopathy by modulating the JAK/STAT signaling pathway in experimental diabetic rats. Drug Des. Devel. Ther. 2016, 10, 2095-2107.

103. Wu, Y.; Xu, M.; Bao, H.; Zhang, J.H. Sitagliptin inhibits EndMT in vitro and improves cardiac function of diabetic rats through the SDF-1 $\alpha$ /PKA pathway. Eur Rev. Med. Pharmacol. Sci. 2019, 23, 841-848. [PubMed]

104. Nogueira, K.C.; Furtado, M.; Fukui, R.T.; Correia, M.R.; Dos Santos, R.F.; Andrade, J.L.; Rossi da Silva, M.E. Left ventricular diastolic function in patients with type 2 diabetes treated with a dipeptidyl peptidase-4 inhibitor-A pilot study. Diabetol. Metab. Syndr. 2014, 6, 103. [CrossRef]

105. Yamada, H.; Tanaka, A.; Kusunose, K.; Amano, R.; Matsuhisa, M.; Daida, H.; Ito, M.; Tsutsui, H.; Nanasato, M.; Kamiya, H.; et al. PROLOGUE Study Investigators. Effect of sitagliptin on the echocardiographic parameters of left ventricular diastolic function in patients with type 2 diabetes: A subgroup analysis of the PROLOGUE study. Cardiovasc. Diabetol. 2017, 16, 63. [CrossRef] [PubMed]

106. Oe, H.; Nakamura, K.; Kihara, H.; Shimada, K.; Fukuda, S.; Takagi, T.; Miyoshi, T.; Hirata, K.; Yoshikawa, J.; Ito, H.; et al. Comparison of effects of sitagliptin and voglibose on left ventricular diastolic dysfunction in patients with type 2 diabetes: Results of the 3D trial. Cardiovasc. Diabetol. 2015, 14, 83. [CrossRef]

107. Scirica, B.M.; Bhatt, D.L.; Braunwald, E.; Steg, P.G.; Davidson, J.; Hirshberg, B.; Ohman, P.; Frederich, R.; Wiviott, S.D.; Hoffman, E.B.; et al. SAVOR-TIMI 53 Steering Committee and Investigators. Saxagliptin and cardiovascular outcomes in patients with type 2 diabetes mellitus. N. Engl. J. Med. 2013, 369, 1317-1326. [CrossRef]

108. Zannad, F.; Cannon, C.P.; Cushman, W.C.; Bakris, G.L.; Menon, V.; Perez, A.T.; Fleck, P.R.; Mehta, C.R.; Kupfer, S.; Wilson, C.; et al. EXAMINE Investigators. Heart failure and mortality outcomes in patients with type 2 diabetes taking alogliptin versus placebo in EXAMINE: A multicentre, randomised, double-blind trial. Lancet 2015, 385, 2067-2076. [CrossRef]

109. Rosenstock, J.; Kahn, S.E.; Johansen, O.E.; Zinman, B.; Espeland, M.A.; Woerle, H.J.; Pfarr, E.; Keller, A.; Mattheus, M.; Baanstra, D.; et al. CAROLINA Investigators. Effect of Linagliptin vs Glimepiride on Major Adverse Cardiovascular Outcomes in Patients With Type 2 Diabetes: The CAROLINA Randomized Clinical Trial. JAMA 2019, 322, 1155-1166. [CrossRef] [PubMed] 
110. Green, J.B.; Bethel, M.A.; Armstrong, P.W.; Buse, J.B.; Engel, S.S.; Garg, J.; Josse, R.; Kaufman, K.D.; Koglin, J.; Korn, S.; et al. TECOS Study Group. Effect of Sitagliptin on Cardiovascular Outcomes in Type 2 Diabetes. N. Engl. J. Med. 2015, 373, $232-242$. [CrossRef]

111. Liberale, L.; Carbone, F.; Camici, G.G.; Montecucco, F. IL-1 $\beta$ and Statin Treatment in Patients with Myocardial Infarction and Diabetic Cardiomyopathy. J. Clin. Med. 2019, 23, 8-1764. [CrossRef] [PubMed]

112. Luo, B.; Li, B.; Wang, W.; Liu, X.; Liu, X.; Xia, Y.; Zhang, C.; Zhang, Y.; Zhang, M.; An, F. Rosuvastatin alleviates diabetic cardiomyopathy by inhibiting NLRP3 inflammasome and MAPK pathways in a type 2 diabetes rat model. Cardiovasc. Drugs. Ther. 2014, 28, 33-43. [CrossRef] [PubMed]

113. Al-Rasheed, N.M.; Al-Rasheed, N.M.; Hasan, I.H.; Al-Amin, M.A.; Al-Ajmi, H.N.; Mohamad, R.A.; Mahmoud, A.M. Simvastatin Ameliorates Diabetic Cardiomyopathy by Attenuating Oxidative Stress and Inflammation in Rats. Oxid. Med. Cell Longev. 2017, 2017, 1092015. [CrossRef] [PubMed]

114. Min, J.J.; Shin, B.S.; Lee, J.H.; Jeon, Y.; Ryu, D.K.; Kim, S.; Shin, Y.H. Effects of Pravastatin on Type 1 Diabetic Rat Heart with or without Blood Glycemic Control. J. Diabetes Res. 2018, 2018, 1067853. [CrossRef] [PubMed]

115. Abdel-Hamid, A.A.; Firgany, A.E.-D.L. Atorvastatin alleviates experimental diabetic cardiomyopathy by suppressing apoptosis and oxidative stress. J. Mol. Histol. 2015, 46, 337-345. [CrossRef]

116. Carillion, A.; Feldman, S.; Na, N.; Biais, M.; Carpentier, W.; Birenbaum, A.; Cagnard, N.; Loyer, X.; Bonnefont-Rousselot, D.; Hatem, S.; et al. Atorvastatin reduces $\beta$-Adrenergic dysfunction in rats with diabetic cardiomyopathy. PLoS ONE 2017, 12, e0180103. [CrossRef]

117. Jia, W.; Bai, T.; Zeng, J.; Niu, Z.; Fan, D.; Xu, X.; Luo, M.; Wang, P.; Zou, Q.; Dai, X. Combined Administration of Metformin and Atorvastatin Attenuates Diabetic Cardiomyopathy by Inhibiting Inflammation, Apoptosis, and Oxidative Stress in Type 2 Diabetic Mice. Front Cell Dev. Biol. 2021, 16, 634900. [CrossRef]

118. Zhang, J.; Cheng, Y.; Gu, J.; Wang, S.; Zhou, S.; Wang, Y.; Tan, Y.; Feng, W.; Fu, Y.; Mellen, N.; et al. Fenofibrate increases cardiac autophagy via FGF21/SIRT1 and prevents fibrosis and inflammation in the hearts of Type 1 diabetic mice. Clin. Sci. 2016, 130, 625-641. [CrossRef]

119. Malmborg, M.; Schmiegelow, M.D.S.; Gerds, T.; Schou, M.; Kistorp, C.; Torp-Pedersen, C.; Gislason, G. Compliance in Primary Prevention With Statins and Associations With Cardiovascular Risk and Death in a Low-Risk Population With Type 2 Diabetes Mellitus. J. Am. Heart Assoc. 2021, 6, e020395. [CrossRef]

120. Cosentino, F.; Grant, P.J.; Aboyans, V.; Bailey, C.J.; Ceriello, A.; Delgado, V.; Federici, M.; Filippatos, G.; Grobbee, D.E.; Hansen, T.B.; et al. ESC Scientific Document Group. 2019 ESC Guidelines on diabetes, pre-diabetes, and cardiovascular diseases developed in collaboration with the EASD. Eur. Heart J. 2020, 41, 255-323. [CrossRef] 